\title{
The Application of Altman's Z-Score Model in Predicting Bankruptcy: Evidence from the Trading Sector in Sri Lanka
}

\author{
Aloy Niresh, J. ${ }^{1}$ \& Pratheepan, T. ${ }^{1}$ \\ ${ }^{1}$ Department of Finance \& Accountancy, Vavuniya Campus of the University of Jaffna, Sri Lanka \\ Correspondence: Aloy Niresh, J., Department of Finance \& Accountancy, Vavuniya Campus of the University of \\ Jaffna, Sri Lanka. E-mail: aloy157@gmail.com
}

Received: September 28, 2015

Accepted: October 21, 2015

Online Published: November 25, 2015

doi:10.5539/ijbm.v10n12p269

URL: http://dx.doi.org/10.5539/ijbm.v10n12p269

\begin{abstract}
Prediction of bankruptcy is crucial as the early warning may change entire complications and may avoid the high cost that is associated with distress. The main purpose of this study is to examine the likelihood of bankruptcy of the firms belonging to the Trading Sector in Sri Lanka. The research used data from the financial reports of seven trading companies for a period of the last five years from 2010 to 2014. Altman's original (1968) bankruptcy model has been applied in order to classify the companies in various levels of financial position namely safe, grey and distress. Findings reveal that $71 \%$ of the companies belonging to the Trading Sector were in financial distress and the rest of whole $29 \%$ were in the grey zone. The fact that none of the companies lie under the safe zone highlights that as a whole the sector is in a menace.
\end{abstract}

Keywords: bankruptcy, distress, financial position and trading sector

\section{Introduction}

\subsection{Background of the Study}

Businesses have been functioning in a highly turbulent environment. Not all businesses survive for long as there are businesses which might come to an end within a very short period from the date of their inception. Contrary to this, some businesses might end up after a long period of time. Businesses carry out various activities so as to make profits and to generate wealth for continuing their operations. Finance will be the backbone for all these activities. Therefore, a firm should be financially sound in order to survive amidst competition.

A firm is said to be bankrupt when it finds itself in a situation where its total liabilities exceed the fair valuation of its total assets. The real net worth of the firm is, therefore negative. The most pervasive reason for a firm's distress and possible failure is some type of managerial incompetence. Even though firms end up in a mess for various reasons, managerial inefficiencies are usually at the core of the problems. Moreover, fraudulent activities of management, international competition, over capacity within an industry, relatively high new business formation rates and high real interest rates in certain periods might be some other reasons which lead to bankruptcy and other distressed conditions which in turn result in corporate failure.

\subsection{Research Objective}

This research intends to examine the likelihood of bankruptcy of the firms which lie under the Trading sector by applying the Altman's original (1968) bankruptcy model.

\subsection{Significance of the Study}

According to Tam and Kiang (1992), prediction of bankruptcy is probably one of the most important business decision making problems as it affects the entire life span of a business. If the firms are financially unsound, then the risk of default will be very high. Investors invest in companies that are financially healthy as risk of default is minimized for them. If not so, investors' confidence in a firm will tend to decrease, ultimately resulting in corporate failure. Therefore, it is imperative for all the organizations to predict their financial health. By doing so, firms can remain in the industry and prevent themselves from being liquidated by taking necessary actions.

\section{Literature Review}

This section presents the literature on one of the most popular and easily obtained metrics named Altman's Z-Score model and some other models and ratios which have been utilized by scholars all around the world for 
predicting financial distress.

\subsection{Altman's Z-Score Model}

Edward I. Altman introduced the Z-Score model in the year 1968 and the model has been well accepted as a financial distress model for almost five decades. Even though several bankruptcy models came into practice, for example, logit analysis, recursive portioning algorithm and neural networks, Altman's model is still considered to be superior and pervasively applied by researchers all over the world.

Altman utilized a statistical technique called Discriminant Analysis to create a financial distress prediction model by integrating the basic financial ratios as inputs to his model. The model formed by Altman for predicting a company's financial health is as follows;

$$
Z=0.012 X_{1}+0.014 X_{2}+0.033 X_{3}+0.006 X_{4}+0.999 X_{5}
$$

Where:

$\mathrm{Z}=$ Overall Index or Score

$\mathrm{X}_{1}=$ Working Capital / Total Assets

$\mathrm{X}_{2}=$ Retained Earnings / Total Assets

$\mathrm{X}_{3}=$ Earnings before Interest \& Tax / Total Assets

$\mathrm{X}_{4}=$ Market Capitalization / Total Liabilities

$\mathrm{X}_{5}=$ Sales / Total Assets

The decision criteria for classifying a firm is as follows;

$Z>2.99$ - The overall index which is greater than 2.99 exemplifies that a firm will less likely go bankrupt. Therefore, if a firm got a $Z$ value of greater than 2.99 , it can be concluded that a firm is in safe zone.

$\mathrm{Z}<1.81$ - The $\mathrm{Z}$ value of less than 1.81 implies that the firm will very likely go bankrupt in the near future. Hence, if a firm has a $Z$ value of less than 1.81 , it is considered to be in the distress zone.

$1.81 \leq \mathrm{Z} \leq 2.99-\mathrm{Z}$ value of anything in between 1.81 and 2.99 indicates that the firm is at the risk of financial distress (grey zone).

\subsection{Description of Variables Used in the Study}

The variables used in the model and their descriptions are as follows;

\subsection{1 $\mathrm{X}_{1}$ : Working Capital to Total Assets}

Working capital over total assets is a measure of liquid assets in relation to the firm's size. Working capital is simply defined as the difference between current assets and current liabilities and it can either be positive or negative. It is good to have positive working capital as it is an indication of a firm's capacity to pay-off its short term obligations.

\subsection{2 $\mathrm{X}_{2}$ : Retained Earnings to Total Assets}

Retained earnings also known as earned surplus is the accumulated amount of reinvested earnings and losses of a firm over its entire life. It is a measure of cumulative profitability over the life of the company. Moreover, it can also be considered as a measure of leverage of a firm. Higher retained earnings to total assets ratio implies that retained earnings have much utilized to finance total assets rather than debt.

\subsection{3 $\mathrm{X}_{3}$ : Earnings before Interest \& Tax over Total Assets}

A firm's ultimate existence is based on the earning capacity of its assets, this ratio appears to be particularly relevant for studies related to corporate failure. It is a version of return on assets, an effective way of assessing a firm's ability to squeeze profits before factors like interest and tax are deducted. The ratio answers to a question that whether the assets are efficiently utilized or not in generating profit.

\subsection{4 $\mathrm{X}_{4}$ : Market Capitalization over Total Liabilities}

It shows how much the firm's assets can decline in value before the liabilities exceed assets and the firm becomes insolvent. This ratio adds a market value dimension that most other failure studies did not consider. According to Chavakhin and Gertmenian (2003), the soundness of a company's financial position gets reflected in its market capitalization. That is, if a firm has significant market capitalization, it should be perceived as an indication of the market's belief in its solid financial position. Furthermore, even if the firm starts experiencing temporary financial difficulties, it could resort to issuing more common stock at relatively high prices if it has 
significant market capitalization.

\subsection{5 $\mathrm{X}_{5}$ : Sales to Total Assets}

It measures the sales generating ability of the firm's assets. It is one measure of management's ability in dealing with competitive conditions. The ratio is the least significant on an individual basis as it was statistically insignificant when it was tested by Altman on a univariate statistical significance test. Despite its unique relationship to other variables in the model, it comes at second in its contribution to the overall discriminating ability of the model.

\subsection{Studies Related to Bankruptcy}

A plethora of studies have been conducted over the past fifty years to evaluate the financial health of a company with the help of various ratios and by applying a great variety of bankruptcy prediction models. Corporate failures are a common problem of developing and developed economies (Altman et al., 1979). Hence predicting corporate failure has been the subject of considerable academic research for nearly five decades. Continued research in corporate failure prediction reflects the importance of the subject.

Predicting corporate failure is crucial as the consequences of it is myriad. Whatever the changes take place in an organization that will ultimately affect its stakeholders. Sun and Feng Hui (2006) believe that bankruptcy brings much individual loss to stakeholders such as creditors, managers, investors, employees and etc. Meanwhile, if the quantum of it is high, it will affect the country's economic development as well.

Altman identified four terms in the literature which have been used to depict the problems confronted by a firm, namely failure, insolvency, default and bankruptcy. These terms are sometimes used interchangeably in the literature, but they are distinctly different in their formal usage. Failure means that the realized rate of return on invested capital with allowances for risk consideration is significantly and continually lower than prevailing rates on similar investments. Insolvency can be further divided into two namely technical insolvency and insolvency in a bankruptcy. Technical insolvency arises when a firm fail to meet its current obligations as a result of inadequate cash flow. Insolvency in a bankruptcy is the condition in which the company's total liabilities exceeds a fair valuation of its total assets. Defaults that can take two forms named technical or legal and always involve the relationship between the debtors and creditors. Technical default takes place when the debtor violates a condition of an agreement with a creditor and can be the ground for legal action. A legal default is more likely when a firm misses a scheduled loan or bond repayment, although it is not always the result in the case of a loan. Bankruptcy is a firm's formal declaration of bankruptcy in a federal district court, accompanied by a petition either to liquidate its assets or to attempt a recovery program.

Altman (1968), in his study of Financial Ratios, Discriminant Analysis and the Prediction of Corporate Bankruptcy found that failing firms exhibit significantly different ratio measurements than continuing entities and the model was $95 \%$ accurate in predicting the financial distress of firms one year prior to their failure. The sample of his study composed of 33 bankrupt firms and 33 non bankrupt firms and the data for a period of 20 years from 1946 to 1965 has been considered for his study.

Gunathilaka (2014) examined the financial distress of 82 companies listed on the Colombo Stock Exchange (CSE) from several industries by way of using the Z-Score models of Altman and Springate. Samples were collected from 2008 to 2012 and analyzed by incorporating Multivariate Discriminant Analysis (MDA). The results were identical, though Altman's Z-Score demonstrated a higher degree of accuracy in predicting the financial distress of the selected Sri Lankan companies at least a year before the distress.

Carson (1995) studied the strength of three types of bankruptcy prediction models named Multiple Discriminant Analysis, Logistic Regression and Recursive Partitioning. Findings reveal that MDA models were superior to other models which were used in the study. Moreover, Keiege (1991) who applied MDA in line with Altman's (1968) model on listed companies in Kenya came to know that ratios best discriminate between un-successful and successful companies appeared to differ from industry to industry. He further observed that financial ratios like current ratio, fixed charge coverage, retained earnings to total assets, return on total assets, return on net worth, average collection period and sales to total assets can be successfully used in predicting corporate failure for a period up to two years at $95 \%$ correct classification.

According to Youn and Gu (2010), Artificial Neural Networks (ANN) model is advantageous over the Logistic Regression model as far as prediction accuracy is concerned. They found that interest coverage is the most important signal of business failure for the Korean hotel industry.

Diakomihalis (2012) utilized all three versions of Altman's model to study the bankruptcy predictions for different classes of hotels in Greece. $Z_{1}$ (original) model is the most accurate having the accuracy rate of $88.2 \%$ 
in predicting bankruptcy a year ahead of the other two versions of the model, findings reveal. Hence the researcher concluded that Altman model can be applied with considerable success to forecast bankruptcy.

Lakshan and Wijekoon (2013) conducted a study on the use of financial ratios in predicting corporate failure in Sri Lanka. The study utilized publicly available data from annual reports of a sample of 70 failed firms and 70 non-failed firms listed on Colombo Stock Exchange for a period from 2002 to 2008 by way of using logistic regression model. A total of 15 ratios were used as predictor variables of corporate failure. They found that the prediction accuracy of the model was $77.86 \%$ one year prior to failure. Moreover, predictive accuracy of the model in all 3 years prior to failure was $72.14 \%$. Hence the model they utilized was robust in obtaining accurate results for up to three years.

\section{Methodology}

\subsection{Data Collection and the Research Sample}

The study relied on secondary data and the data was extracted from the financial statements of firms belonging to the Trading sector. Specifically, items in the income statement and statement of financial position of each firm in the sample were collected. The time frame for the data being collected covering a period of the last 5 years from 2010 to 2014. Eight companies are listed under the Trading sector. Out of this, seven companies were selected as a sample for this study as the data for the Mackie PLC for the year of 2010 was not obtainable. The following table shows a mere representation of the sample firms used in the study.

Table 1. Selected trading companies

\begin{tabular}{ll}
\hline Name of the Company & Symbol \\
\hline Brown \& Company PLC & BRWN.N0000 \\
Eastern Merchants PLC & EMER.N0000 \\
Office Equipment PLC & OFEQ.N0000 \\
Radiant Gems International PLC & RGEM.N0000 \\
Singer Sri Lanka PLC & SINS.N0000 \\
Ceylon \& Foreign Trades PLC & CFT.N0000 \\
Tess Agro PLC & TESS.N0000 \\
\hline
\end{tabular}

\section{Findings \& Analysis}

4.1 Measures of Central Tendency

Table 2. Descriptive statistics of the variables used in the study

\begin{tabular}{llllll}
\hline Variable & Range & Minimum & Maximum & Mean & Std. Deviation \\
\hline Z Value & 2.17 & 0.25 & 2.42 & 1.17 & 0.81 \\
WCTA & 0.68 & $(0.03)$ & 0.65 & 0.14 & 0.23 \\
RETA & 1.64 & $(1.00)$ & 0.64 & 0.79 & 0.51 \\
EBITTA & 0.27 & 0.001 & 0.27 & 0.09 & 0.09 \\
MCTL & 1.57 & 0.36 & 1.93 & 0.98 & 0.57 \\
STA & 2.18 & 0.24 & 2.42 & 1.16 & 0.81 \\
\hline
\end{tabular}

Note. WCTA: Working Capital over Total Assets; RETA: Retained Earnings to Total Assets; EBITTA: Earnings before Interest \& Tax to Total Assets; MCTL: Market Capitalization over Total Liabilities; STA: Sales over Total Assets.

As you can see from Table 2, the mean value of $Z$ score is 1.17 . The mean $Z$ value is less than 1.81 and it exemplifies that the Trading Sector as a whole is in the distress zone. The standard deviation of $Z$ value and Sales to Total Assets are high as the range, which is 2.17 and 2.18 respectively, is found to be high for them. Moreover, the $\mathrm{Z}$ value varies in between 0.25 and 2.42, indicating that none of the firms listed under the Trading Sector are financially sound. 


\subsection{Classification of Firms Based on Average Z Values}

Table 3. Average $Z$ values and the classification of selected companies

\begin{tabular}{lll}
\hline Firm & Average Z Value & Zone \\
\hline BRWN.N0000 & 0.42 & Distress \\
EMER.N0000 & 2.42 & Grey \\
SINS.N0000 & 1.17 & Distress \\
OFEQ.N0000 & 1.98 & Grey \\
RGEM.N0000 & 0.60 & Distress \\
CFT.N0000 & 0.25 & Distress \\
TESS.N0000 & 1.35 & Distress \\
\hline
\end{tabular}

It is apparent from Table 3 that out of seven, five companies fall under the distress zone and the rest fall under the grey zone. It reveals that $71 \%$ of the total of the companies are very likely to go bankrupt in the future and the rest of $29 \%$ are also at the risk of financial distress. Since none of the firms belong to the safe zone, there are chances for the whole industry to collapse.

\subsection{Trend Analysis

\begin{tabular}{|c|c|c|c|c|c|c|c|c|}
\hline 2010 BRWN & - 2011 BRWN & 2012 BRWN & 2013 BRWN & 2014 BRWN & 2010 EMER & - 2011 EMER & - 2012 EMER & - 2013 EMER \\
\hline 2014 EMER & 2010 SINS & 2011 SINS & 2012 SINS & 2013 SINS & 2014 SINS & 2010 OFEQ & 2011 OFEQ & 2012 OFEQ \\
\hline 2013 OFEQ & 2014 OFEQ & 2010 RGEM & 2011 RGEM & - 2012 RGEM & — 2013 RGEM & 2014 RGEM & $2010 \mathrm{CFT}$ & $=2011 \mathrm{CFT}$ \\
\hline 2012 CFT & 2013 CFT & 2014 CFT & 2010 TESS & 2011 TESS & -2012 TESS & 2013 TESS & 2014 TESS & \\
\hline
\end{tabular}

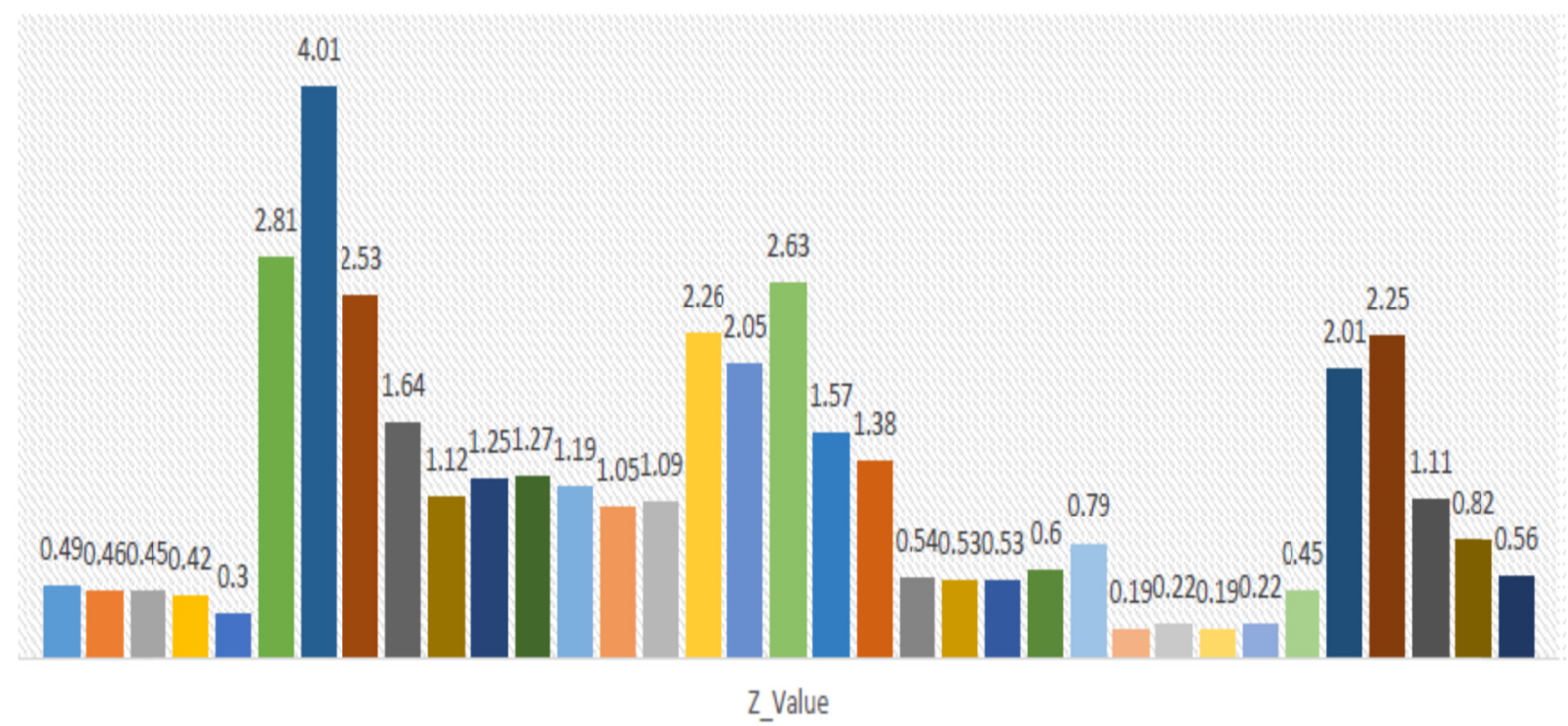

Figure 1. Z values of the selected firms from 2010 to 2014 
Table 4. Z values and the firms' classification

\begin{tabular}{|c|c|c|c|}
\hline Company & Year & $\mathrm{Z}$ value & Zone \\
\hline \multirow[t]{5}{*}{ BRWN.N0000 } & 2010 & 0.49 & Distress \\
\hline & 2011 & 0.46 & Distress \\
\hline & 2012 & 0.45 & Distress \\
\hline & 2013 & 0.42 & Distress \\
\hline & 2014 & 0.30 & Distress \\
\hline \multirow[t]{5}{*}{ EMER.N0000 } & 2010 & 2.81 & Grey \\
\hline & 2011 & 4.01 & Safe \\
\hline & 2012 & 2.53 & Grey \\
\hline & 2013 & 1.64 & Distress \\
\hline & 2014 & 1.12 & Distress \\
\hline \multirow[t]{5}{*}{ SINS.N0000 } & 2010 & 1.25 & Distress \\
\hline & 2011 & 1.27 & Distress \\
\hline & 2012 & 1.19 & Distress \\
\hline & 2013 & 1.05 & Distress \\
\hline & 2014 & 1.09 & Distress \\
\hline \multirow[t]{5}{*}{ OFEQ.N0000 } & 2010 & 2.26 & Grey \\
\hline & 2011 & 2.05 & Grey \\
\hline & 2012 & 2.63 & Grey \\
\hline & 2013 & 1.57 & Distress \\
\hline & 2014 & 1.38 & Distress \\
\hline \multirow[t]{5}{*}{ RGEM.N0000 } & 2010 & 0.54 & Distress \\
\hline & 2011 & 0.53 & Distress \\
\hline & 2012 & 0.53 & Distress \\
\hline & 2013 & 0.60 & Distress \\
\hline & 2014 & 0.79 & Distress \\
\hline \multirow[t]{5}{*}{ CFT.N0000 } & 2010 & 0.19 & Distress \\
\hline & 2011 & 0.22 & Distress \\
\hline & 2012 & 0.19 & Distress \\
\hline & 2013 & 0.22 & Distress \\
\hline & 2014 & 0.45 & Distress \\
\hline \multirow[t]{5}{*}{ TESS.N0000 } & 2010 & 2.01 & Grey \\
\hline & 2011 & 2.25 & Grey \\
\hline & 2012 & 1.11 & Distress \\
\hline & 2013 & 0.82 & Distress \\
\hline & 2014 & 0.56 & Distress \\
\hline
\end{tabular}

As you can see from Table 4, there are four companies which were in the distress zone during the five-year time period considered for the study namely Brown \& Company PLC, Singer Sri Lanka PLC, Radiant Gems International PLC and Ceylon Foreign Trades PLC. A cautious attention has to be paid as the consequences will definitely be not in favor of these companies. If this situation continues it will likely to affect investments in the firms and the current investors will likely to sell their shares and there will not be any potential investments as well. Furthermore, solvency of the firms will become questionable and there will not be any opportunities for the firms to grow as finance is the foundation for achieving growth. Only one company (Eastern Merchants PLC) was in the safe zone in the year of 2011, with the $Z$ value of 4.01 . However, it fell under grey zone in the following year and distress zone in the subsequent two years of 2013 and 2014. All these indicate that the firms which lie under the Trading Sector were financially unsound for the time period considered for the study. Hence, necessary actions should be taken by the corporate management of all companies to keep them financially sustainable.

\section{Conclusion}

This study investigated the applicability of the Altman's original (1968) bankruptcy model to examine the financial soundness of the firms belonging to the Trading Sector. Seven companies were selected as sample for this study and the data for a period of last five years from 2010 to 2014 has been taken into consideration. There is a greater likelihood that the firms listed under the Trading Sector go bankrupt in the near future, findings 
reveal. Moreover, none of the firms listed under the Trading Sector were financially sound. Hence, the ultimate responsibility is vested in the hands of top management to bring their organizations back on track or to build them up as financially sound since it is beneficial to the companies, its stakeholders and eventually to the country.

\section{References}

Altman, E. I. (1968). Financial Ratios, Discriminant Analysis and the Prediction of Corporate Bankruptcy. The Journal of Finance, 23(4), 589-609. http://dx.doi.org/10.1111/j.1540-6261.1968.tb00843.x

Altman, E. I., \& Hotchkiss, E. (2006). Corporate Financial Distress and Bankruptcy (3rd ed.). John Wiley \& Sons, Inc., Hoboken, New Jersey.

Carson M. J. (1995). Financial Distress in the Life Insurance Industry: An Empirical Examination. Illinois University.

Cecilia, W. R. (2003). Bankruptcy Prediction: The Case of the CLECS. American Journal of Business, 18(1), 71-82. http://dx.doi.org/10.1108/19355181200300006

Diakomihalis, M. (2012). The accuracy of Altman's models in predicting hotel bankruptcy. International Journal of Accounting and Financial Reporting, 2.

Gunathilaka, C. (2014). Financial Distress Prediction: A Comparative Study of Solvency Test and Z-Score models with reference to Sri Lanka. The IUP Journal of Financial Risk Management, 11(3), 40-50.

Joseph, \& Calandro, J. R. (2007). Considering the utility of Altman's Z-score as a strategic assessment and performance management tool. Strategy \& Leadership, 35(5), 37-43. http://dx.doi.org/10.1108/10878570710819206

Keige, P. N. (1991). Business Failure Prediction using Discriminate Analysis. Unpublished MBA research work, UON.

Lakshan, A. M. I., \& Wijekoon, W. M. H. N. (2013). The use of Financial Ratios in Predicting Corporate Failure in Sri Lanka. GSTF Journal of Business Review (GBR), 2(4), 37-43.

Scott, J. (1981). The probability of bankruptcy: A comparison of empirical predictions and theoretical models. Journal of Banking \& Finance, 5, 318-344. http://dx.doi.org/10.1016/0378-4266(81)90029-7

Sun, J., \& Hui, X. F. (2006). Financial Distress Prediction based on Similarity Weighted Voting. CBR, 947-958. http://dx.doi.org/10.1007/11811305_103

Tam, K. Y., \& Kiang, M. Y. (1992). Managerial Applications of Neural Networks: The Case of Bank Failure Predictions. Management Science, 38(7), 926-947. http://dx.doi.org/10.1287/mnsc.38.7.926

Youn, H., \& Gu, Z. (2010). Predicting Korean lodging firm failures: An artificial neural network model along with a logistic regression model. International Journal of Hospitality Management, 29, 120-127. http://dx.doi.org/10.1016/j.ijhm.2009.06.007

\section{Copyrights}

Copyright for this article is retained by the author(s), with first publication rights granted to the journal.

This is an open-access article distributed under the terms and conditions of the Creative Commons Attribution license (http://creativecommons.org/licenses/by/3.0/). 